\title{
Changing Subjects, Changing Places
}

\author{
Penn Kemp
}

\section{Changer le sujet, changer de place}

Les textes se propagent en réseau à partir des sujets d'énonciations multiples, décentrés. Le labyrinthe des mots, des métaphors - tant de médiations - trahit la douleur du corps souffrant d'endométriose. Cette maladie nommée les rêves se manifestent en tant que représentations du corps. Les codes du genre fonctionnent dans le flux des hormones. Mais c'est encore une réduction. Plutôt, le sujet de l'énonciation a decodéles signes selon une autre herméneutique. Tout commele kaléidoscope, ils se deployent dans beaucoup de récits. Avec chaque nouvelle formulation des signes, le sujet change de place, se divise, se dédouble à l'infini. Du sujet à l'objet, de l'objet en sujet dans le jeu du signifiant.

I,I,I,I, the cry of pain, ay ay, the blink of an I. There's a kaleidoscope of subjects in this me, each one sure of her position when she is at the throttle of consciousness. At the threshold, each one vows to accommodate the others, and then when she achieves control forgets the shadows behind her. Ahem. Attention, please. Writing for me is a process of remembering the others in me. No, that's wrong. Each voice writes her own concern. And then is recognized as singular when read back later. By whom? Another voice. Is there no central subject? I admit a confusion of voices, so far from integrated that they don't even believe in that possibility.

The assorted voices' idea of centre is just a hit of circumstance, and that by luck. Can you tell I'm bluffing, putting in time, fishing? The words come of their own accord, pulled up by a cord from the well of association. Circus, so come, circumvent, you can't make me! —circumference, that's it! Their idea of centre is a hit on the circumference. That's what I meant to say, I say with relief and a glance askance at the 
time line. Has anyone noticed? The posture of wit is desperation, post sure. Letting the language lead has become a necessity these days.

The I who is writing feels begrudgingly betrayed. Also glad, grateful, to be able to get words down coherently-sometimes. And why? I am white, in the middle of life, educated, in a relationship of partners, almost (even) middle class (again). No-one out there is constraining me, comparatively. But I have been wrong. Poetry has betrayed me. Metaphor has betrayed me. My body dominates me. For fifteen years the pain I felt translated immediately into image, which I tried to get down on the page. Get down, it's got me down. So much for sublimation. I cannot walk. I cannot think. Meditation smoothed the pain, but the process in my body went on subliminally. One I must have known what the others did not.

I don't mean there isn't the usual horrible medical story: I went to my family gynecologist with all my symptoms listed, time after time, for years. He laughed at my partner's suggestion of endometriosis and suggested I see a psychiatrist. Moving to Toronto, I changed gynecologists. Four days after my first visit, my new doctor had given me a laproscopy and found endometriosis. My symptoms were classic. Particles of menstrual blood had escaped my womb and implanted themselves outside on my womb, on my bladder. So there is that reality. Four months later, after trying Chinese medicine, anabolic steroids, I can't wait, imagine, I am praying for a hysterectomy. I am on the call list.

The medical reality undiagnosed, my body unrepresented. The coding unread. Creativity gone amuck. Those little red endometrions spreading through my body cavity. Now it is easier to interpret the following dream, from 1986:

'The little red devil lives in a secret closet in the front hall of my house. Deciding to confront him, I climb into his hovel and grapple with him fiercely. But I have bitten off more than I can chew, the devil has transformed into a tiger. The contest is too intense and I am in danger of losing, transformed with the tiger into swirling ghee. Suddenly, I become a monkey, excitedly chittering, teasing the roaring tiger below. Leaping from cupboard to cupboard, I scold as he lunges full force, never quite high enough. Glowering and balefully intent, he tries to stare me down, tail waving ominously. Impasse. Slowly, smoothly, the gorgeous tiger stripes fade away into the tall, dark 
image of an old lover of mine. Dapper, the man reaches out his arms for me, and I allow myself to be coaxed down from the ceiling, seduced, a woman once more.

Suddenly, the scene shifts to my bed, as if I have awakened. But I haven't. I am aware of my lover, fully present, his body pressing into mine. He tells me he loves me deeply and will always be a part of me. 'But I need to be away from you, not to see you.'

So now I have reduced the relationship between male and female to the shifting balance of hormones. A new reductionism. My own shifting metaphor has ruled my subjects. I have lived by the prevailing metaphor of my dreams. As if it were real. Yesterday, I dreamt a molar fell out with a clunk: and that prepares my body to accept the shock of a hysterectomy. You see?

So alright, it is not the failure of metaphor per se. My body was trying to tell me all those years, dream after dream. The little red dogs yapping at my heels, the red monkeys swinging from trees, the barnacles clinging to the dolphin: perfect metaphors for the endometrial blood that has escaped the uterus. Demon lovers ride the fluctuating tide of progesterone. So clear in hindsight. But hermeneutics let me down. My perception let me down. I have not been able to walk five yards for over a year and a half; something let me down.

Let me give the kaleidoscope another whirl, into laboroscope, her/story. My life has been changing the subject. A new explanation, and my shape shifts again. My $(w)$ hole definition of myself has been through birthing as creativity. While the metaphor holds, my body could not. I forgot to ask, births what? At what cost? My pelvis split giving birth to my first child, and seven times since. In many ways that split reflects profoundly a change in self/shape from child/woman to woman with child who splits ad infinitum. Am I subject to objectification; that nothing is wholly good. And I object, but the subject shifts the shape around and

subject shifts shape shift

sub text

sup press

ex stant

express

ex plain

happen stance 
Changing Subjects, Changing Places · 95

predictable predicate

the past a ghast

store up sort of

hurt but too

confused to

notice

so many of us home

I don't know who to call

subject to change

without notice

change the subject

no certainty need apply

surely

explain as the no's

on my face

effaced by

wrinkles

who could foresee?

'the trick is to act as act if could if active would apply' pass if the am you knit shun

unravelled sleeve of

care

carry on

I carry

Icarus via

us

vye

carious

carrion

dead meat

carry on the race

is to the quick

erased in

dead heat

merry we meet and 
merry part

'a nation of women with wings'

we are

weary

let down defences

I have needed explanations, stories to explain predicaments not predictable . Look to the physical, what is the simplest. Here I am, flat, having invested myself in rationale. Because of misdiagnosis, because doctors don't take women seriously. I take a clear body signal and translate it into emotional pain and make myself guilty for it. Guilt for feeling pain, for not being able to rise above the signals of my own body, of having to interpret my own body language into metaphor when what I needed was to give what for to the con / man doctor who laughed at my stories and left me in pain.

shape shifting from round limbs of childhood to round belly of twelve to round breasts to rounder bellies to split pelvis to sprained pelvis to strained pelvis, salmon fall apart in the brooks where they spawn cartilage splayed, and now

Fifteen years ago, my shape was shifting, and I had an abortion, a tubal cauterization. Fire charred those wings and I fell. That is another story, clipped. Shall I sharpen Occam's Razor? During this procedure, some tissue from my endometrium escaped from my uterus and implanted itself in tiny colonies in my body cavity, and on my pelvic ligaments. Each month, these colonies would respond to the hormonal signals, and shed blood, tissue. This caused pain which was at times so debilitating that I could not stand or walk. To cope with the pain, I relied on meditative techniques that took me out of my body. Over time, the endometrial implants interfered with my body's production of hormones.

One of the results of the abnormal hormonal flow was that I experienced vivid hypnagogic images. Because I am a poet, I took these visions as a blessing, and used them as guides. Whole poems came to me in this state. Other visions also came. I translated the pain from endometriosis into horrifying dreams in which I was ritually tortured and abused by men. So many of the visions had blood and red in them. I read The Wise Wound and thought I was blessed with extraordinary vision. I now believe the visions to be attempts to cope with unremitting pain. 
The prose before my world view shifts once again. My whole system crosses signals. These June days of perfection mist, I drift across some enormity, shawled and coiffed, the images I drew for years of gap, of poignancy for the past and the future, the present. These red poems talk to me now. Re-reading them, I am astonished at the clues in them I couldn't decipher at the time of writing. 'I!' said The Little Red Hen and she did. 'Off!' said the little Red Queen and she did.

Swampy terrain indeed!

My body the jungle, the slough of despond.

The cruelty of metaphor the vision I couldn't share now released

out of the shift once more into the breech

last will and test a manny

breech that birth!

I've been wrong!

wronged and

rung out

the barrels

bring out the arrows, Eros

danazoi, dazzling anabolicly

testestarone a test

progesterone

pro jest? you must be

joking. This project

is a test.

toss her among

imposters among

these thieves,

small honour.

the Goddess within is

turning out

to be 


\section{$98 \cdot$ Tessera}

way

ward

endometrium

endo, I learn to call it

in the support group,

the endo support group.

The end of

disparity

the depths of this

pair

her suit

strong suit

nirsuite bear, an ox

ymoronic pun

Who's to say when another reality, another (realized) birth, will suddenly pop alive and kicking into our lives? It would sometimes seem to take forever to translate. Sometimes it's been there all along and I never noticed it until now. And yet I've been trying to think the relationship intra subject through for years.

Bits of paper,

snippets and segments.

Pages add to pages

an aesthetic.

Hypnogogic state.

The spell. The voice reels by my mind

on tickertape, left to right.

I wonder what its direction would be

if I spoke Hebrew or Chinese.

I remember the process

and lose the words.

Those words loom so large, the billboard of mind.

They resonate. How could they drop into the word forever? Irretrievable. But the process, 
Changing Subjects, Changing Places · 99

I catch, and cotton on to.

Glimmer.

An emotion too bare to say.

Light explodes as I go under.

The end of the tunnel

become the means.

I remember the empty brilliance

of a page imagined.

I remember sleep, slipping

back

to sweet

nothings, no

syllables chime

into chords.

Murmur I promise

to remember, to re-

collect recall

down the long red hall of

memory

revisited

the poem parts

the poem leaps

synapse, the poem

appropriates

all as proper

for its own

soi-propre

soi-disant

distant

relative

blood

kin 
kindling

how we claim all

as metaphor, image

of that yearning fashion

calls desire

red and ribbed, blood

vesseled, we have been

here before

the poem repeats old

patterns even after

years, yearning for

the new

the new physics, theories

out of chaos, the dissipative

structure leaps to a new

order

my, mind, mined

red and ribbed, blood

vesseled, re/membered

as mother culture, my blood

red wine has soured.

Vinegar in my wine skin.

Red and white goddesses

terracotta

so easy to crack.

Crack the code, the egg cossetted.

Culled.

Sure.

Be tray.

Last night I dreamt

the Fyfe's cat cracked

open. Inside sat blinking 
Changing Subjects, Changing Places · 101

a giant toad that could only

be born by cracking the clay.

I cant keep up

appearance

shifts

I cant keep up

The Goddess this Lammas wants

blood and she has

mine

so far benign.

Creativity berserk, my womb

shot endo's out to far walls.

Womb out you must now represent all

the loss I leave bleeding

free flow

flaw 